\title{
Economic Security of Organizations: Industry Formalization of Its Indicators
}

\author{
Evgeny P. Ivanov ${ }^{1, *}$, Elena E. Rodina ${ }^{1}$, Maksim A. Rodin $^{1}$, Lyudmila M. \\ Makarova $^{1}$, Irina A. Mandych ${ }^{2}$ \\ ${ }^{1}$ Moscow Academy of Finance and Law (MFUA), Moscow, Russia \\ ${ }^{2}$ MIREA - Russian technological university, Moscow, Russia \\ *Corresponding author. Email: kep2006@mail.ru
}

\begin{abstract}
The article is devoted to the issue of formation of indicators intended for the assessment by textile organizations of their economic security as a key condition for the functioning and development prospects of all organizations, including this national economic sector, which is a set of universal directions of the national economy of a mass nature, without which the life of people in professional and domestic life is impossible, requiring knowledge and application of indicators to assess its real level, serving as a yardstick in taking appropriate anti-crisis measures. The study is based on the final and intermediate desired benchmarks (goals and objectives). The goal is to offer and justify the formed system of indicators of the economic security of textile organizations, based on the author's position, focused on the effectiveness and cost (direct and indirect profitability) of economic processes and justified by commodity-money relations interacting with market laws inherent in the modern era, in which they carry out their activities along with other economic entities. The objectives of the study to achieve it are the study of sectoral economic cycles and other elements of productive forces in the textile industry correlated with them, the choice and application of methods and techniques (computationalconstructive and inductive methods) in the formation of this system of indicators. Using such knowledge, a system of general and particular indicators of the effectiveness and cost of the activities of textile organizations has been built, and their formalized relationship is shown, which allows them to quickly identify reserves for optimizing financial benefits. The provided material can be useful for persons engaged in theoretical and applied developments in the field of ensuring the economic security of organizations in the textile industry and other industries in terms of a general methodological approach based on uniform scientific principles.
\end{abstract}

Keywords: economic security, organizations, textile industry, efficiency, cost.

\section{INTRODUCTION}

The textile industry is of great strategic importance for the development of the domestic economy, since it belongs to the branches of light industry, which is a sphere of mass production, the mission of which is aimed at meeting the needs and requirements of all social groups, regardless of status, priority in material and spiritual values. Therefore, for the organizations involved in it, the key issue is economic security - the basic factor of continuous and stable functioning, which determines their resistance to the existing economic environment. Maintaining economic security provides them with constant competitive advantages and a long life cycle, due to which they are able to maintain and maintain leadership positions and regularly combine their own and public interests. In view of the indisputability of this fact, the authors consider the issue of the formation of indicators of the economic security of textile organizations to be relevant, by which they will be able to objectively evaluate it and make reasoned management decisions to extract benefits with the highest value.

In the following sections of the topic under study, we will reveal in detail this important issue, which includes materials and methods (final and intermediate guidelines, methods and techniques used), discussion of the subject and object (a formed system of indicators of the economic security of textile organizations, based on certain indicators and their technological cycles) of the study and conclusion (generalized conclusions on the study, supported by its practical significance). 


\section{MATERIALS AND METHODS OF THE STUDY}

The final desired benchmark (goal) in the study is a reasoned offer of the developed author's system of indicators of the economic security of organizations engaged in the to financial insolvency and bankruptcy, built on the effectiveness (direct profitability) and cost (indirect profitability) of business processes through commodity-money relations with market laws, under which textile organizations operate together with other economic entities at the present. The intermediate desired benchmarks (tasks) of our study include the study of sectoral business cycles, consisting of several business operations (the object under study), in the process of which the result (profit) and costs (expenses) are formed and the selection of the desired resulting indicators (the object under study) for them reflecting the level of economic security of textile organizations. The specified benchmarks will be achieved using a combination of computational-constructive and inductive methods that ensure the integrity of the developed statistical dependencies that combine the resulting and factor indicators of the economic security of textile organizations, the organic nature of their interaction with each other in the course of calculating the selected final (general) indicators, which manifests itself in formalized structuring, revealing the strength (degree) of the impact of each of the composite (element-wise) relative indicator on the aggregate performance and aggregate cost. Thanks to them, they will promptly analyze the degree of importance of particular parameters in calculating the general parameters of activities and make the necessary adjustments to strengthen their economic security.

\section{DISCUSSION}

The calculation of the resulting indicators of the economic security of textile organizations shall begin with building the structure of its factor indicators (results and costs). To do this, let us define the sectoral economic processes of these organizations, appealing to their economic core. The papers of E.G. Andrianov, S.A. Golovin, S.V. Zykov, S.A. Lesko, E.R. Chukalina (Andrianova, 2020), A.A. Itygina (Itygina, 2014), O.G. Kantor (Kantor, 2020), N.S. Rychikhina (Rychikhina, 2013), S.A. Sybachin (Sybachin, 2017), N.M. Filimonova (Filimonova, 2018), O.G. Chetverikova (Chetverikova, 2019) understand it as the technological economic process, where, according to gradation, the raw material factor is in priority. Publications owned by A.F. Baranova (Baranova, 2019), M.A. Kovtun (Kovtun, 2019), O.V. Melnikova (Melnikova, 2020), I.K. Shevchenko (Shevchenko, 2019) contain information about the overhead business process, especially about the infrastructure problem. Synthesizing the provisions from both groups of literary sources and supplementing it with other economic operations in terms of the main and overhead economic process, we will group the cost items of textile organizations according to them.

The technological (main) economic process is associated with the production of fabric (the main activity), which includes four business operations (Table $1)$.

Table 1. The main economic process of textile organizations

\begin{tabular}{|l|l|}
\hline Business operations & \multicolumn{1}{|c|}{ Monetary expression } \\
\hline $\begin{array}{l}\text { Primary processing } \\
\text { of raw materials }\end{array}$ & $\begin{array}{l}\text { Costs for cleaning raw materials } \\
\text { from seeds and impurities and } \\
\text { obtaining fibers }\end{array}$ \\
\hline Spinning & $\begin{array}{l}\text { Costs of processing the resulting } \\
\text { fibers into yarn }\end{array}$ \\
\hline Weaving & Yarn fabric production costs \\
\hline Finishing & $\begin{array}{l}\text { Expenses for cleaning fabric from } \\
\text { impurities }\end{array}$ \\
\hline
\end{tabular}

Source: author's development

The overhead business process is represented by infrastructural, managerial and commercial business operations (Table 2).

Table 2. Overhead economic process of textile organizations

\begin{tabular}{|l|l|}
\hline $\begin{array}{c}\text { Business } \\
\text { operations }\end{array}$ & \multicolumn{1}{|c|}{ Monetary expression } \\
\hline Infrastructure & $\begin{array}{l}\text { Expenses of energy, instrumental, repair, } \\
\text { transport, storage units providing primary } \\
\text { processing of raw materials, spinning, } \\
\text { weaving, finishing }\end{array}$ \\
\hline Managerial & $\begin{array}{l}\text { The costs of managing departments } \\
\text { involved in the primary processing of raw } \\
\text { materials, spinning, weaving, finishing, } \\
\text { their interaction with each other and with } \\
\text { other business departments }\end{array}$ \\
\hline Commercial & $\begin{array}{l}\text { Costs for transportation, insurance, } \\
\text { bringing to consumers of textile products }\end{array}$ \\
\hline
\end{tabular}

Source: author's development

It is in an integrated form that they represent total costs (factor indicators of the economic security of textile organizations). We will compare this factor indicator with the result, adhering to the general methodological foundations of calculating the effectiveness and cost of the activities of organizations, presented in the papers of S.Yu. Ilyin (Ilyin, 2016; Ilyin, 2018; Ilyin, 2018), A.S. Krasnikova (Krasnikova, 2018), I.A. Mandych (Mandych, 2021), G. Ya. Ostaev (Ostaev, 2018; Ostaev, 2018), helping to understand the essence and content of computational actions in the field of assessing the studied indicators of economic security. Since the activities of textile organizations are subordinated to commoditymoney relations, and they are mostly with commercial organizational and legal forms, according to the authors, in the formation of indicators of their economic security, one must proceed, firstly, from the rationality of economic processes of direct and indirect content 
(efficiency and cost), and secondly, to evaluate it by profitability (direct and indirect profitability). It is this concept that complies with the market laws concerning, first of all, commercial organizations, non-compliance with which subsequently leads to the above negative consequences.

Following it, we obtain the following performance and cost indicators of the main and overhead economic processes of textile organizations (formulas (1), (2), (3), (4)):

$$
\begin{aligned}
& \mathrm{EB}_{\text {to }(\mathrm{op})}=\frac{\mathrm{P}_{\mathrm{tp}}}{\mathrm{R}_{\mathrm{pos}}+\mathrm{R}_{p}+\mathrm{R}_{t}+\mathrm{R}_{\mathrm{o}}} \\
& =\frac{1}{\mathrm{~EB}_{\mathrm{pos}(k)}+\mathrm{EB}_{p(k)}+\mathrm{EB}_{t(k)}+\mathrm{EB}_{\mathrm{o}(k)}}
\end{aligned}
$$

where $\mathrm{EB}_{\text {to(op) }}$ - direct economic security (profitability) of the main economic process of textile organizations; $\mathrm{P}_{\mathrm{tp}}$ - profit from sales of textile products, rubles; $R_{\text {pos }}$ - costs of primary processing of raw materials, rubles; $R_{p}$ - spinning costs, rubles; $R_{t}$ - weaving costs, rubles; $\mathrm{R}_{\mathrm{t}}$ - finishing costs, rubles; $\mathrm{EB}_{\mathrm{pos}(\mathrm{k})}$ - indirect economic safety of the process of primary processing of raw materials; $\mathrm{EB}_{\mathrm{p}(\mathrm{k})}$ - indirect economic safety of the spinning process; $\mathrm{EB}_{\mathrm{t}(\mathrm{k})}$ - indirect economic security of the weaving process; $\mathrm{EB}_{\mathrm{o}(\mathrm{k})}$ - indirect economic safety of the finishing process;

$$
\begin{aligned}
& \mathrm{EB}_{\mathrm{to}(\mathrm{ok})}=\frac{\mathrm{R}_{p o s}+\mathrm{R}_{p}+\mathrm{R}_{t}+\mathrm{R}_{\mathrm{o}}}{\mathrm{P}_{\mathrm{tp}}}=\frac{1}{\mathrm{~EB}_{p o s(p)}}+\frac{1}{\mathrm{~EB}_{p(p)}}+ \\
& \frac{1}{\mathrm{~EB}_{t(p)}}+\frac{1}{\mathrm{~EB}_{\mathrm{o}(p)}},
\end{aligned}
$$

where $\mathrm{EB}_{\text {to (ok) }}$ - indirect economic security (cost of profit) of the main economic process of textile organizations; $R_{\text {pos }}$ - costs of primary processing of raw materials, rubles; $\mathrm{R}_{\mathrm{p}}$ - spinning costs, rubles; $\mathrm{R}_{\mathrm{t}}$ - weaving costs, rubles; $\mathrm{R}_{\mathrm{o}}$ - finishing costs, rubles; $\mathrm{P}_{\mathrm{tp}}$ - profit from sales of textile products, rubles; $\mathrm{EB}_{\mathrm{pos}(\mathrm{p})}$ - direct economic safety of the primary processing of raw materials; $\mathrm{EB}_{\mathrm{p}(\mathrm{p})}$ - direct economic safety of the spinning process; $\mathrm{EB}_{\mathrm{t}(\mathrm{p})}$ direct economic security of the weaving process; $\mathrm{EB}_{\mathrm{o}(\mathrm{p})}$ direct economic safety of the finishing process;

$$
\begin{aligned}
& \mathrm{EB}_{\mathrm{to}(\mathrm{np})}=\frac{\mathrm{P}_{\mathrm{tp}}}{\mathrm{R}_{i t}+\mathrm{R}_{u t}+\mathrm{R}_{k t}}= \\
& \frac{1}{\mathrm{~EB}_{i t(k)}+\mathrm{EB}_{u t(k)}+\mathrm{EB}_{k t(k)}},
\end{aligned}
$$

where $\mathrm{EB}_{\mathrm{to}}$ (np) - direct economic security (profitability) of the overhead economic process of textile organizations; $\mathrm{P}_{\mathrm{tp}}$ - profit from sales of textile products, rubles; $\mathrm{R}_{\mathrm{it}}$ - infrastructure textile costs, rubles; $\mathrm{R}_{\mathrm{ut}}$ - textile management expenses, rubles; $\mathrm{R}_{\mathrm{kt}}$ - commercial textile expenses, rubles; $\mathrm{EB}_{\mathrm{it}(\mathrm{k})}$ - indirect economic security of the infrastructure textile process; $\mathrm{EB}_{\mathrm{ut}(\mathrm{k})}$ - indirect economic security of the management textile process; $\mathrm{EB}_{\mathrm{kt}(\mathrm{k})}$ - indirect economic security of the commercial textile process;

$\mathrm{EB}_{\mathrm{to}(\mathrm{nk})}=\frac{\mathrm{R}_{i t}+\mathrm{R}_{u t}+\mathrm{R}_{k t}}{\mathrm{P}_{\mathrm{tp}}}=\frac{1}{\mathrm{~EB}_{i t(p)}}+\frac{1}{\mathrm{~EB}_{u t(p)}}+$

$\frac{1}{\operatorname{EB}_{k t(p)}}$,

where $\mathrm{EB}_{\text {to(nk) }}$ is the indirect economic security (cost of profit) of the overhead economic process of textile organizations; $\mathrm{R}_{\mathrm{it}}$ - infrastructure textile costs, rubles; $\mathrm{R}_{\mathrm{ut}}$ - textile management expenses, rubles; $\mathrm{R}_{\mathrm{kt}}$ - commercial textile expenses, rubles; $\mathrm{P}_{\mathrm{tp}}$ - profit from sales of textile products, rubles; $\mathrm{EB}_{\mathrm{it}(\mathrm{p})}$ - direct economic security of the infrastructure textile process; $\mathrm{EB}_{\mathrm{ut}(\mathrm{p})}$ - direct economic security of the management textile process; $\mathrm{EB}_{\mathrm{kt}(\mathrm{p})}$ direct economic security of a commercial textile process.

The first and third indicators reflect the amount of profit from the sale of textile products per unit of basic and overhead textile expenses (direct profitability of the activities of textile organizations). The second and fourth indicators mean the size of the main and overhead textile costs per unit of profit from the sale of textile products (indirect profitability of the activities of textile organizations). Both groups of indicators, on the one hand, are not contradictory in relation to general economic indicators of performance and cost, on the other hand, they are focused on the patterns of conducting textile activities and are closely related through formalized dependencies using the applied research method.

By integrating the pairwise formed homogeneous private (main and overhead) direct and indirect indicators of the economic security of textile organizations (formulas (1), (3) and (2), (4)), we will construct its general (aggregate) indicators (formulas (5), (6)):

$\mathrm{EB}_{\mathrm{to}(p)}=\frac{1}{\mathrm{~EB}_{\mathrm{to}(o \mathrm{k})}+\mathrm{EB}_{\mathrm{to}(\mathrm{nk})}}$,

where $\mathrm{EB}_{\mathrm{to}(\mathrm{n})}$ is the aggregate direct economic security (aggregate profitability) of textile organizations; $\mathrm{EB}_{\mathrm{to}(\mathrm{ok})}$ - indirect economic security of the main economic process of textile organizations; $\mathrm{EB}_{\text {to }}(\mathrm{nk})$ indirect economic security of the overhead economic process of textile organizations;

$\mathrm{EB}_{\mathrm{to}(\mathrm{k})}=\frac{1}{\mathrm{~EB}_{\mathrm{to}(\mathrm{op})}}+\frac{1}{\mathrm{~EB}_{\mathrm{to}(\mathrm{np})}}$,

where $\mathrm{EB}_{\text {to }}(\mathrm{k})$ is the aggregate indirect economic security (aggregate cost of profit) of textile organizations; $\mathrm{EB}_{\mathrm{to}(\mathrm{op})}$ - direct economic security of the main economic process of textile organizations; $\mathrm{EB}_{\mathrm{to}(\mathrm{np})}$ - direct economic 
security of the overhead economic process of textile organizations.

According to these indicators, textile organizations will be able to accurately assess the general parameters of efficiency and cost and establish the necessary proportions between the effectiveness and cost of the main and overhead business processes that affect them, as well as balance these structural factor components and, thereby, optimize the level of their economic security.

\section{CONCLUSION}

The indicators formed in the course of the study organically fit into the traditional system of understanding efficiency and cost and, at the same time, correspond to industry laws, as a result of which they are appropriate for use by textile organizations to assess economic security. They will serve as objective guidelines for them in carrying out reasonable measures for planning results and costs, which will contribute to the maximum margin of their economic strength with the best financial benefits and strong market positions in comparison with competitors. The practical significance of the study lies in the possibility of using the system of indicators proposed by the authors for a comprehensive assessment by textile organizations of the effectiveness and cost of their activities, timely identification of reserves, increasing and strengthening their economic security without incurring imputed costs due to accurate ranking of the degree of influence of various factor parameters on it.

\section{REFERENCES}

[1] E.G. Andrianova, S.A. Golovin, S.V. Zykov, S.A. Lesko, E.R. Chukalina, Review of modern models and methods for analyzing time series of dynamics of processes in social, economic and socio-technical systems. Russian technological magazine, 8 (4) (2020) pp. 7-45. DOI: https://doi.org/10.32362/2500-316X-2020-8-4-745.

[2] A.F. Baranova, S.N. Mamedov, I.V. Pogodina. Circular economy in the textile industry, News of higher educational institutions. Textile industry technology, 5(383) (2019) pp. 36-42.

[3] S.Yu. Ilyin. Modern trends in the development of the economics of organizations, Chasopis ekonomichnykh reform, 3(23) (2016) pp. 22-28.

[4] S.Yu. Ilyin, Cost indicators of the efficiency of agricultural organizations, Agrarian scientific magazine, 6 (2018) pp. 86-89.

[5] A.A. Itygina, Analysis of the state and development prospects of the textile industry in Russia, Economics, Sociology and Law, 2 (2014) pp. 37-45.

[6] O.G. Kantor, Yu.A. Kuznetsova, Analysis of the resource potential of the textile and clothing industry on the basis of production functions, News of higher educational institutions. Textile industry technology, 6(390) (2020) pp. 5-11.

[7] M.A. Kovtun, O.V. Saradzheva, Economic security of light industry in Russia, Economy today: current state and development prospects (Vector-2019), 2019, pp. 184-187.

[8] A.S. Krasnikova, Research of problems of interfunctional coordination at industrial enterprises, Bulletin of the Moscow State Regional University. Series: Economics, 4 (2018) pp. 67-74.

[9] O.V. Melnikova, Yu.A. Dmitriev, A.B. Petrukhin, Present and future of the textile industry of the Ivanovo region, News of higher educational institutions. Textile industry technology, 1(385) (2020) pp. 5-8.

[10] G.Ya. Ostaev, B.N. Khosiev, A.S. Klychova, Management accounting: management of financial flows of agricultural enterprises, Bulletin of Kazan State Agrarian University, 13(3(50)) (2018) pp. 134-139.

[11] G.Ya. Ostaev, G.S. Klychova, E.V. Nekrasova, Making managerial decisions: mechanisms and financial instruments, Bulletin of Kazan State Agrarian University, 13(4(51)) (2018) pp. 146-152.

[12] N.S. Rychikhina, Analysis of the stages of the "life cycle" of the development of the textile industry in the Ivanovo region, Economy and Banks, 2 (2013) pp. 88-96.

[13] S.A. Sybachin, L.A. Kuranova, Improving the efficiency of the national economy on the example of textile industry enterprises, News of higher educational institutions. Textile industry technology, 6(372) (2017) pp. 11-15.

[14] N.M. Filimonova, E.V. Gavrilin, A.T. Petrova, Enterprise flexibility - as a factor in the efficiency of the textile industry enterprises, News of higher educational institutions. Textile industry technology, 2(374) (2018) pp. 110-112.

[15] O.G. Chetverikova, L.R. Girfanova, Increasing the efficiency of development of the raw material base of light industry in the Russian Federation, Bulletin of Ufa State Petroleum Technological University. Science, education, economics. Series: Economics, 2(28) (2019) pp. 51-59.

[16] I. K. Shevchenko, Yu. V. Razvadovskaya, A. A. Marchenko, Textile industry in Russia: history and modernity, Terra Economicus, 17(1) (2019) pp. 131-149.

[17] S. Y. Ilyin, Tools for calculating the development indicators of the economy of organizations, International Journal of Civil Engineering and Technology, 9(8) (2018) pp. 1681-1688. 